\title{
Assessment of the Coal-Bed Gas Total Petroleum System in the Cook Inlet-Susitna Region, South-Central Alaska
}

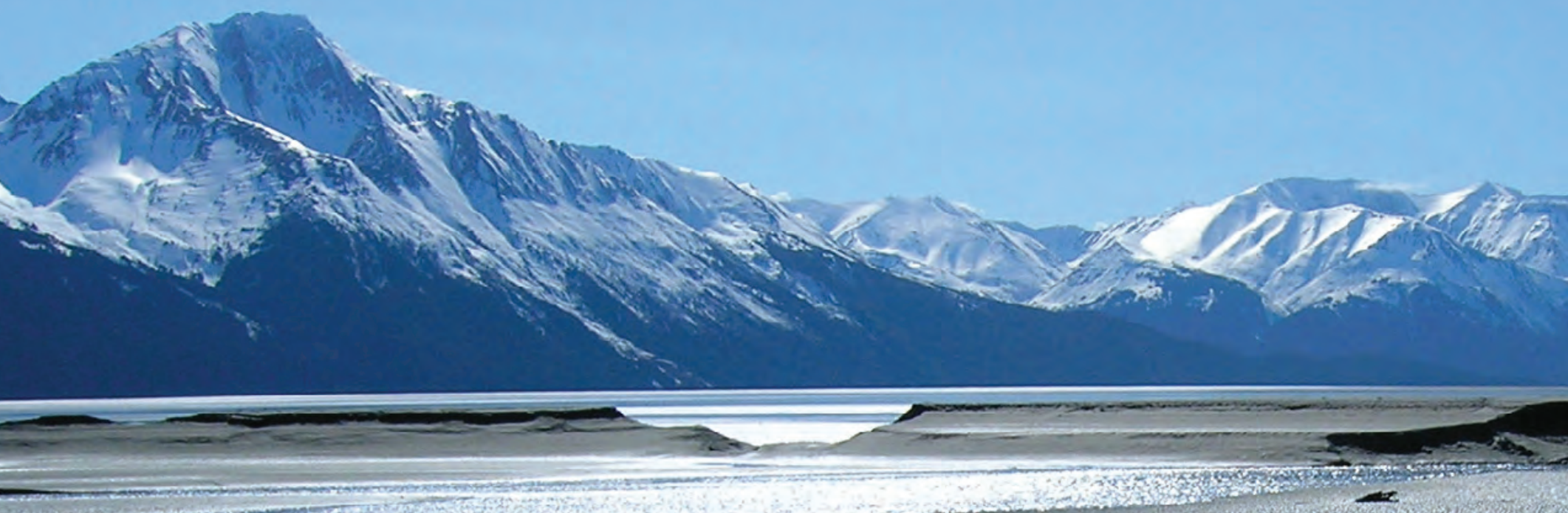

9

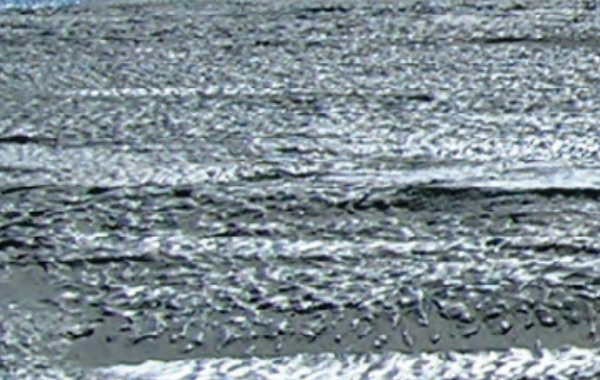

3.7. \section{Scientific nvestigations Réport 201225145}

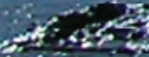

U.S. Department of theilnteijor
U.S. Geological Survey 
Cover photo. View to the southwest across intertidal sand flat along theTurnagain Arm of the Cook Inlet with Kenai-Chugach Mountains in background. Sand flat is located near Girdwood, Alaska, on northern shore of Turnagain Arm, and distance to mountains on southern shore is approximately 7 kilometers (4.3 miles). 


\section{Assessment of the Coal-Bed Gas Total Petroleum System in the Cook Inlet-Susitna Region, South-Central Alaska}

By William A. Rouse and David W. Houseknecht

Scientific Investigations Report 2012-5145 


\title{
U.S. Department of the Interior \\ KEN SALAZAR, Secretary \\ U.S. Geological Survey \\ Marcia K. McNutt, Director
}

\author{
U.S. Geological Survey, Reston, Virginia: 2012
}

For more information on the USGS - the Federal source for science about the Earth, its natural and living resources, natural hazards, and the environment, visit http://www.usgs.gov or call 1-888-ASK-USGS.

For an overview of USGS information products, including maps, imagery, and publications, visit http://www.usgs.gov/pubprod

To order this and other USGS information products, visit http://store.usgs.gov

Any use of trade, firm, or product names is for descriptive purposes only and does not imply endorsement by the U.S. Government.

Although this information product, for the most part, is in the public domain, it also may contain copyrighted materials as noted in the text. Permission to reproduce copyrighted items must be secured from the copyright owner.

Suggested citation:

Rouse, W.A., and Houseknecht, D.W., 2012, Assessment of the Coal-Bed Gas Total Petroleum System in the Cook Inlet-Susitna region, south-central Alaska: U.S. Geological Survey Scientific Investigations Report 2012-5145, 19 p. 


\section{Contents}

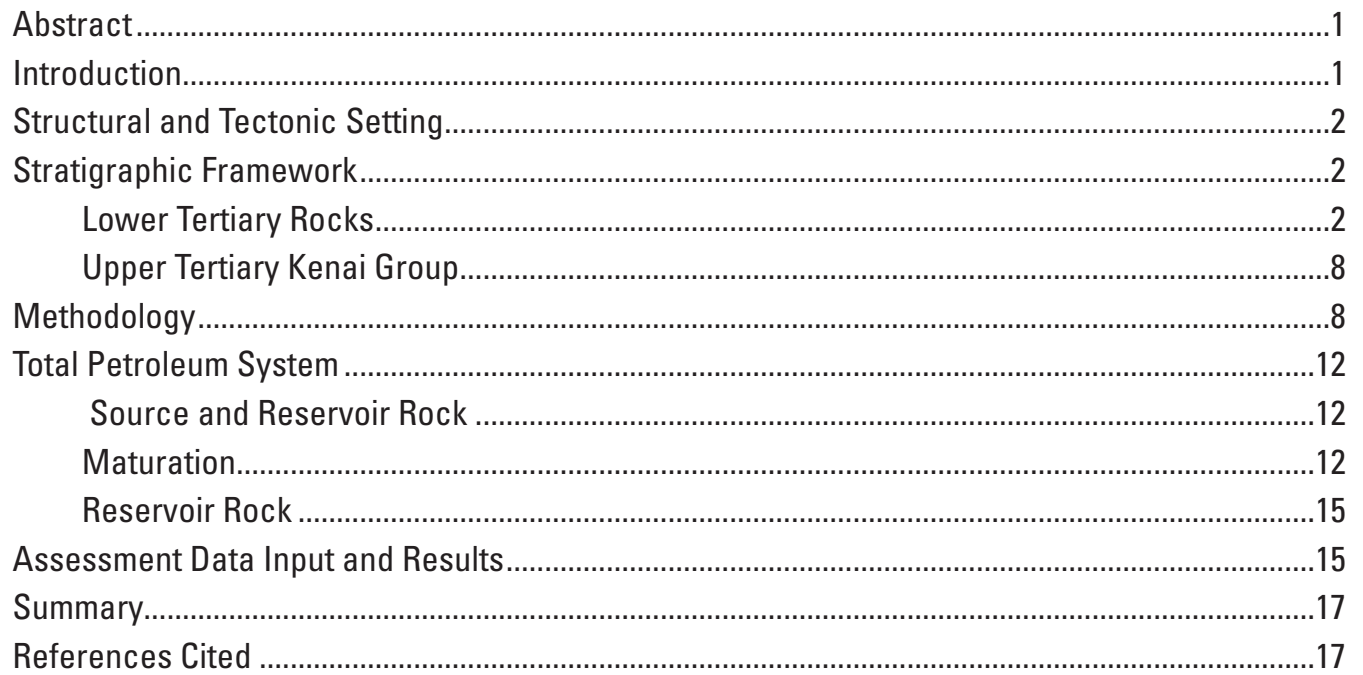

\section{Figures}

1. Location of the Cook Inlet Coal-Bed Gas Total Petroleum System (TPS), major bounding faults, anticlines, and vertical and near-vertical well locations within the Cook Inlet-Susitna region, south-central Alaska ................................

2. Tectonic and volcanic settings of the Cook Inlet basin.....................................................4

3. Cross section of the eastern Aleutian Arc, from Mount Spurr to the Border Ranges fault, Alaska ............................................................................................. 5

4. Tertiary correlation chart for the Cook Inlet-Susitna region ..............................................6

5. Depositional model of the Kenai Group in the Cook Inlet basin .........................................7

6. Well log response of coal and borehole washout intervals in the

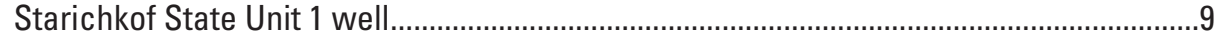

7. Cumulative thickness of coal (in feet) as inferred from records of wells between 1,000 and 6,000 feet deep in the Cook Inlet basin. .............................................10

8. Location of wells with thick coal deposits between depths of 1,000 and 6,000 feet in the Cook Inlet basin ....................................................................11

9. Structure contour map of the top of the Mesozoic basement, Cook Inlet basin .............13

10. Outcrop and well vitrinite reflectance values within the Coal-Bed Gas Total Petroleum System (TPS) in the Cook Inlet-Susitna region.....

\section{Tables}

1. Assessment data input for the Cook Inlet Coal-Bed Gas Assessment Unit .16

2. Summary of results for risked, undiscovered, technically recoverable contiguous gas resources for the Cook Inlet Coal-Bed Gas Assessment Unit 


\section{Conversion Factors}

\begin{tabular}{|c|c|c|}
\hline Multiply & By & To obtain \\
\hline \multicolumn{3}{|c|}{ Length } \\
\hline meter $(\mathrm{m})$ & 3.281 & foot $(\mathrm{ft})$ \\
\hline meter $(\mathrm{m})$ & 1.094 & yard (yd) \\
\hline kilometer (km) & 0.6214 & mile (mi) \\
\hline mile (mi) & 1.609 & kilometer $(\mathrm{km})$ \\
\hline \multicolumn{3}{|c|}{ Area } \\
\hline acre & 0.004047 & square kilometer $\left(\mathrm{km}^{2}\right)$ \\
\hline \multicolumn{3}{|c|}{ Volume } \\
\hline cubic centimeter $\left(\mathrm{cm}^{3}\right.$ or $\left.\mathrm{cc}\right)$ & 0.06102 & cubic inch $\left(\right.$ in $\left.^{3}\right)$ \\
\hline cubic foot $\left(\mathrm{ft}^{3}\right)$ & 28.32 & cubic decimeter $\left(\mathrm{dm}^{3}\right)$ \\
\hline cubic foot $\left(\mathrm{ft}^{3}\right)$ & 0.02832 & cubic meter $\left(\mathrm{m}^{3}\right)$ \\
\hline \multicolumn{3}{|c|}{ Mass/weight } \\
\hline gram $(\mathrm{g})$ & 0.03527 & ounce, avoirdupois (oz avdp) \\
\hline ton & 0.9072 & megagram $(\mathrm{Mg})$ or metric ton $(\mathrm{t})$ \\
\hline
\end{tabular}

The isotope ratio of carbon-13 to carbon-12 relative to the Pee Dee Belemnite (PDB), in per mil, is notated as $\delta 13 \mathrm{C}$. 


\title{
Assessment of the Coal-Bed Gas Total Petroleum System in the Cook Inlet-Susitna Region, South-Central Alaska
}

\author{
By William A. Rouse and David W. Houseknecht
}

\section{Abstract}

The Cook Inlet-Susitna region of south-central Alaska contains large quantities of gas-bearing coal of Tertiary age. The U.S. Geological Survey in 2011 completed an assessment of undiscovered, technically recoverable coal-bed gas resources underlying the Cook Inlet-Susitna region based on the total petroleum system (TPS) concept. The Cook Inlet Coal-Bed Gas TPS covers about 9,600,000 acres and comprises the Cook Inlet basin, Matanuska Valley, and Susitna lowland. The TPS contains one assessment unit (AU) that was evaluated for coal-bed gas resources between 1,000 and 6,000 feet in depth over an area of about 8,500,000 acres.

Coal beds, which serve as both the source and reservoir for natural gas in the AU, were deposited during PaleocenePliocene time in mires associated with a large trunk-tributary fluvial system. Thickness of individual coal beds ranges from a few inches to more than 50 feet, with cumulative coal thickness of more than 800 feet in the western part of the basin. Coal rank ranges from lignite to subbituminous, with vitrinite reflectance values less than 0.6 percent throughout much of the AU.

The AU is considered hypothetical because only a few wells in the Matanuska Valley have tested the coal-bed reservoirs, so the use of analog coal-bed gas production data was necessary for this assessment. In order to estimate reserves that might be added in the next 30 years, coal beds of the Upper Fort Union Formation in the Powder River Basin of Wyoming and Montana were selected as the production analog for Tertiary coal beds in the Cook Inlet-Susitna region. Upper Fort Union coal beds have similar rank (lignite to subbituminous), range of thickness, and coal-quality characteristics as coal beds of the Tertiary Kenai Group. By use of this analog, the mean total estimate of undiscovered coal-bed gas in the Tertiary Coal-Bed Gas AU is 4.674 trillion cubic feet (TCF) of gas.

\section{Introduction}

The U.S. Geological Survey (USGS) in 2011 completed an assessment of undiscovered, technically recoverable, conventional and unconventional oil and gas resources in the Cook Inlet-Susitna region of south-central Alaska. The assessment is based on the total petroleum system (TPS) concept (Schmoker, 2005) and includes four assessment units (AU). Results of the complete assessment were reported by Stanley and others (2011). The purpose of this report is to provide a synthesis of the geology of the Cook Inlet-Susitna region and to present input parameters and results of the Cook Inlet CoalBed Gas TPS resource assessment.

Coal was first discovered in Alaska at Port Graham on the Kenai Peninsula by Russian explorers in 1786, although it was undoubtedly used by native Alaskans earlier (Merritt and Hawley, 1986). The Russian-American Company opened the first documented coal mine in Alaska in 1855 at this site, exporting 88 tons of coal to California in its first year (Davis, 1981; Merritt and Hawley, 1986). Since then, as much as 12 billion short tons of coal have been discovered in the Cook Inlet-Susitna region, with estimates of undiscovered or hypothetical coal resources at 1,600 billion short tons (Hopkins, 1951, cited in Flores and others, 2003; Barnes and Cobb, 1959; Barnes, 1967; Renshaw, 1983; Merritt and Belowich, 1984; Merritt and Hawley, 1986; Affolter and Stricker, 1987).

Production of gas from conventional sandstone and conglomerate reservoirs began in 1958, and more than 7.8 trillion cubic feet (TCF) have been produced (Alaska Department of Natural Resources, Division of Oil and Gas, 2009). As much as 93 percent of the natural gas discovered to date may have been sourced from coal interbedded with the conventional sandstone and conglomerate reservoirs (Claypool and others, 1980). Geochemical evidence suggests that most of the coalbed-sourced gas in Cook Inlet conventional accumulations is biogenic rather than thermogenic, because biogenic gas gener- 
ated from coal beds is isotopically light $\left(\delta^{13} \mathrm{C}\right.$ range of -63 to -56 per mil) and chemically dry $\left(\mathrm{C}_{1} / \mathrm{C}_{1-5}>0.99\right.$; Claypool and others, 1980).

The large amount of coal in the Cook Inlet-Susitna region, coupled with moderate to good gas content, suggests the potential for a large untapped coal-bed gas resource. Although no official estimates of coal-bed gas resources in the Cook Inlet-Susitna region have been published previously by the USGS, a total gas-in-place resource of 245 TCF was estimated by Montgomery and Barker (2003).

\section{Structural and Tectonic Setting}

The Cook Inlet basin is a northeast-southwest trending fore-arc basin flanked by the Aleutian volcanic arc to the northwest and Chugach-Kenai accretionary complex to the southeast and bounded by active high-angle reverse fault zones (fig. 1). The Castle Mountain and Bruin Bay fault zones make up the northern and northwestern boundaries, separating the uplifted volcanic arc complex from the basin. The southeastern boundary is defined by the Border Ranges fault, which separates the basin from the Chugach terrane.

Basin accommodation for more than 25,000 feet (ft) of Tertiary nonmarine strata is attributed to early Tertiary deformation and increased tectonism associated with the subduction of the Kula plate and spreading center in the Early Eocene (fig. 2) (Byrne, 1979, cited in Swenson, 1997; Pavlis, 1982). Tertiary strata are thickest in the basin center and thin towards the basin margins (fig. 3). Rapid subsidence and deposition of nonmarine sand, organic matter, and silt continued until the end of the Pliocene, when the latest phase of tectonism deformed the basin margins.

Numerous fault-cored folds related to this latest phase of tectonism are present in the Cook Inlet, with fold axes that are generally subparallel to the margins of the basin and trend northeast-southwest (Plafker and others, 1994). These folds are generally asymmetric and doubly plunging, with opposing sense of vergence, and are thought to be developed by righttranspressional deformation on oblique-slip faults extending downward into Mesozoic basement (Nokleberg and others, 1994; Haeussler and others, 2000). Right-transpressional deformation of the Cook Inlet likely is driven by a combination of subduction of the Pacific plate and lateral escape of the fore arc to the southwest resulting from the collision of the Yakutat block to the east of the basin (Haeussler and others, 2000). Much of the exploration and production activity in the Cook Inlet basin to date has focused on the fault-cored folds.

The Susitna lowland (fig. 1) is considered the northern extension of the Cook Inlet basin, located between the Talkeetna Mountains to the east and the Alaska Range to the north and west (Miller and Dobrovolny, 1959; Smith, 1995). The Susitna arch, a partially buried ridge of granitic rocks near the Castle Mountain fault zone, separates the shallower and younger Susitna lowland from the Cook Inlet basin (Kelly, 1963; Smith, 1995).
The Matanuska Valley is considered the northeastern arm of the Cook Inlet basin, forming a structural trough 8 to 16 kilometers $(\mathrm{km})$ wide and $80 \mathrm{~km}$ long that narrows to the northeast (Merritt and Belowich, 1984). The valley is between the Talkeetna Mountains to the north and Chugach Mountains to the south. The Castle Mountain fault to the north and an unnamed fault zone to the south separate Tertiary and Cretaceous rocks of the Matanuska Valley from older and more highly deformed metamorphic and intrusive rocks of the mountains (Barnes and Payne, 1956). Deformation of coal-bearing rocks and abundance of igneous dikes and sills increase eastward, resulting in coals that are strongly folded and faulted and of higher rank compared to coals of the Cook Inlet and Susitna lowland (Merritt and Belowich, 1984; Stricker, 1991).

\section{Stratigraphic Framework}

Tertiary nonmarine, coal-bearing basin fill unconformably overlies deeply buried, mostly marine Mesozoic rocks (fig. 4). Six regional, time-transgressive units were defined on the basis of "type" well logs by Calderwood and Fackler (1972). These units are thought to contain laterally equivalent facies related to a dynamic nonmarine depositional system (Swenson, 1997). The coarsest facies (conglomerates and sandstones) were deposited near the source by an alluvial fan system that drained the basin margins, while a distal axialfluvial system in the center of the basin reworked the alluvial fan deposits (Flores and others, 2004) (fig. 5). Coal deposits accumulated in mires related to this large fluvial drainage system.

\section{Lower Tertiary Rocks}

Lower Tertiary rocks in the Cook Inlet-Susitna region include the Paleocene-Eocene Chickaloon Formation and Eocene Wishbone Formation. The Chickaloon Formation is present in the northeastern part of the basin and crops out in the Matanuska Valley. This formation consists of a 3,300- to 4,900-ft-thick sequence of mudstone, siltstone, and sandstone, with minor conglomerate and coal (Triplehorn and others, 1984; Flores and Stricker, 1993). Sandstone beds are erosionally based and range from lenticular to tabular in geometry. As many as 12 coal beds have been reported in the Chickaloon Formation. Coal beds are lenticular and vary in thickness within $300 \mathrm{ft} \mathrm{laterally.} \mathrm{Individual} \mathrm{coal} \mathrm{beds} \mathrm{average}$ less than $3 \mathrm{ft}$ in thickness, but a coal bed more than $15 \mathrm{ft}$ thick has been reported in the Chickaloon mine (Wahrhaftig and others, 1994). Coal rank increases from west to east within the Matanuska Valley, from high-volatile subbituminous to semianthracite. This increase in rank is attributed to heating of the coal by the abundant igneous dikes and sills within the Chickaloon Formation in the eastern Matanuska Valley (Merritt, 1985; Stricker, 1991; Wahrhaftig and others, 1994). 


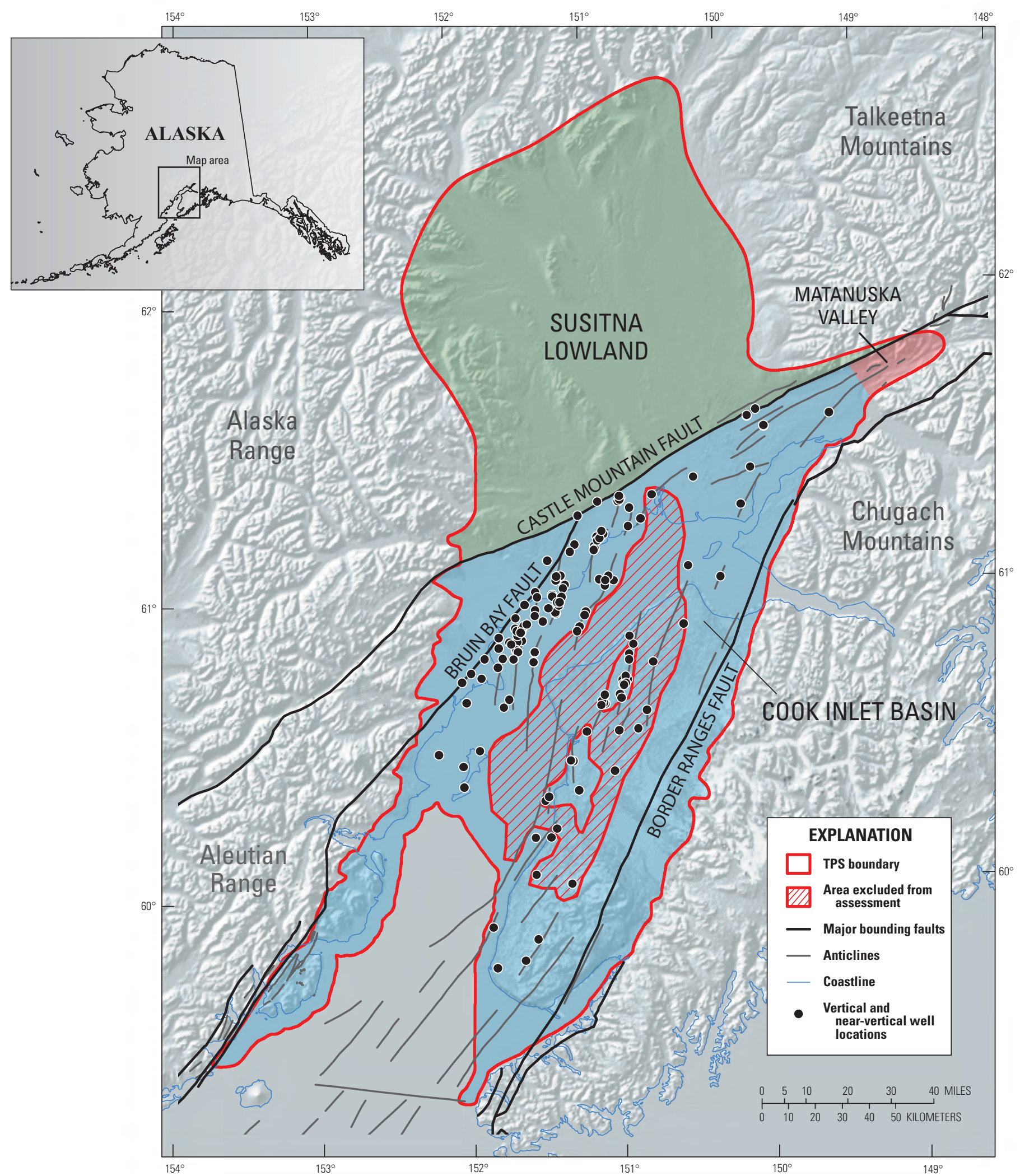

Figure 1. Location of the Cook Inlet Coal-Bed Gas Total Petroleum System (TPS), major bounding faults, anticlines, and vertical and near-vertical well locations within the Cook Inlet-Susitna region, south-central Alaska. The Coal-Bed Gas Assessment Unit (AU) excludes an area in the center of the Cook Inlet basin where the principal coal-bearing units are deeper than 6,000 feet and are unlikely to be productive of gas. An area (not shown) around the outer perimeter of the AU where the principal coal-bearing units are shallower than 1,000 feet also is excluded from the assessment. 


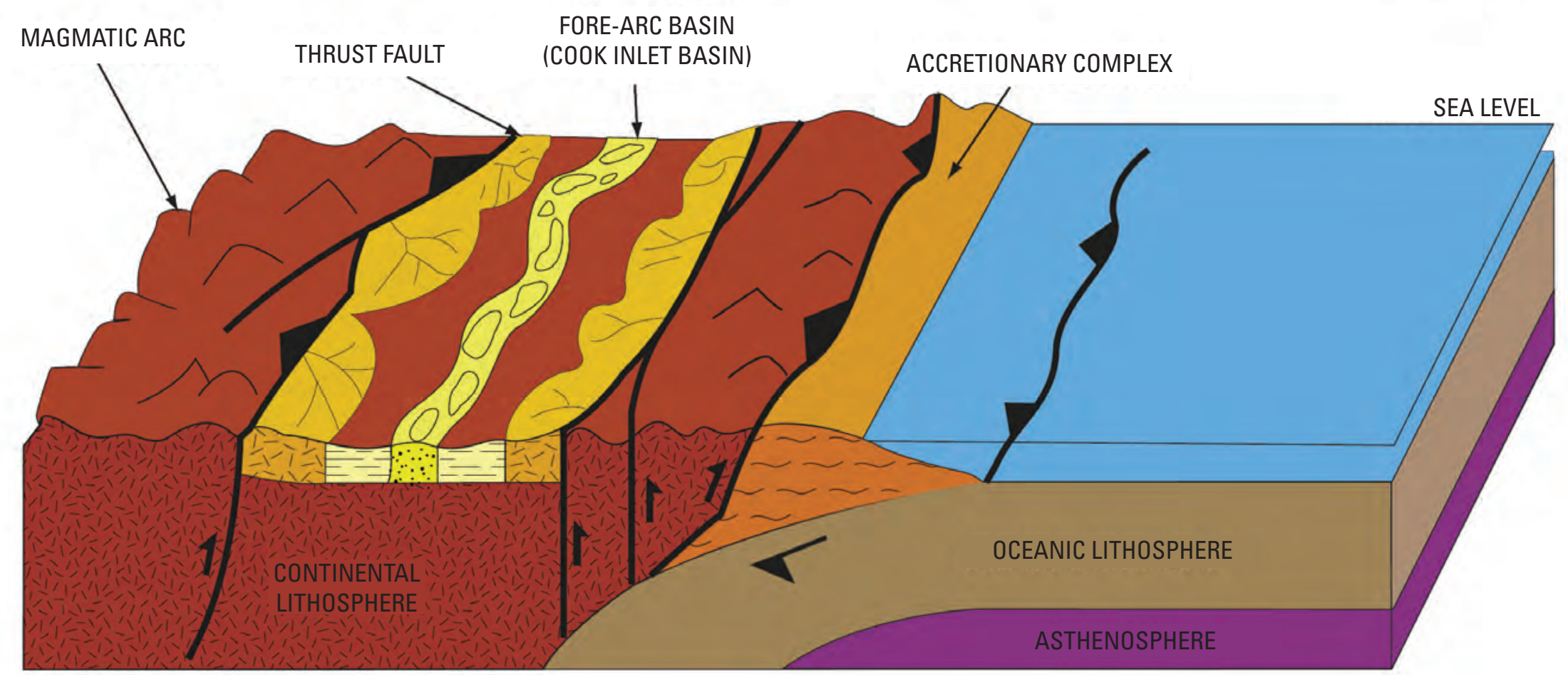

Figure 2. Tectonic and volcanic settings of the Cook Inlet basin (Flores and others, 2004; modified from Swenson, 1997). 


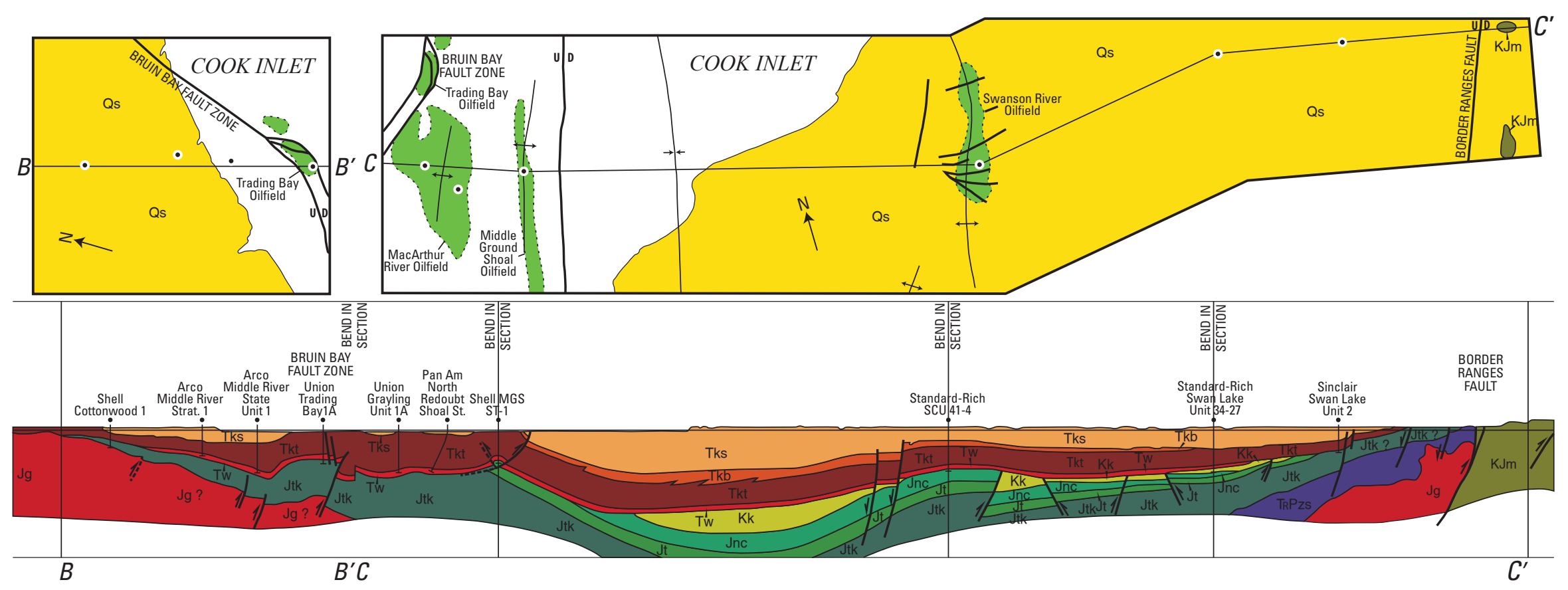

\section{EXPLANATION}

\section{Quartenary sediments}

Kenai Group (Pliocene, Miocene, and Oligocene)

Tks Sterling Formation (Pliocene and Miocene)

Tkb Beluga Formation (Miocene)

Tkt Tyonek Formation and Hemlock Conglomerate (Miocene and Oligocene)

Tw West Foreland Formation (Eocene and Paleocene)

Kk Kaguyak Formation (Upper Cretaceous)
McHugh Complex (Cretaceous and (or) Upper Jurassic)

Chinitna and Naknek Formations (Upper Jurassic)

Tuxedni Group (Middle Jurassic)

Talkeetna Formation (Lower Jurassic)

Granitic rocks (Lower and Middle Jurassic)

Schist and (?) associated ultramafic rocks (Triassic and (or) upper Paleozoic)

Figure 3. Cross section of the eastern Aleutian Arc, from Mount Spurr to the Border Ranges fault, Alaska (modified from Plafker and others, 1982). 


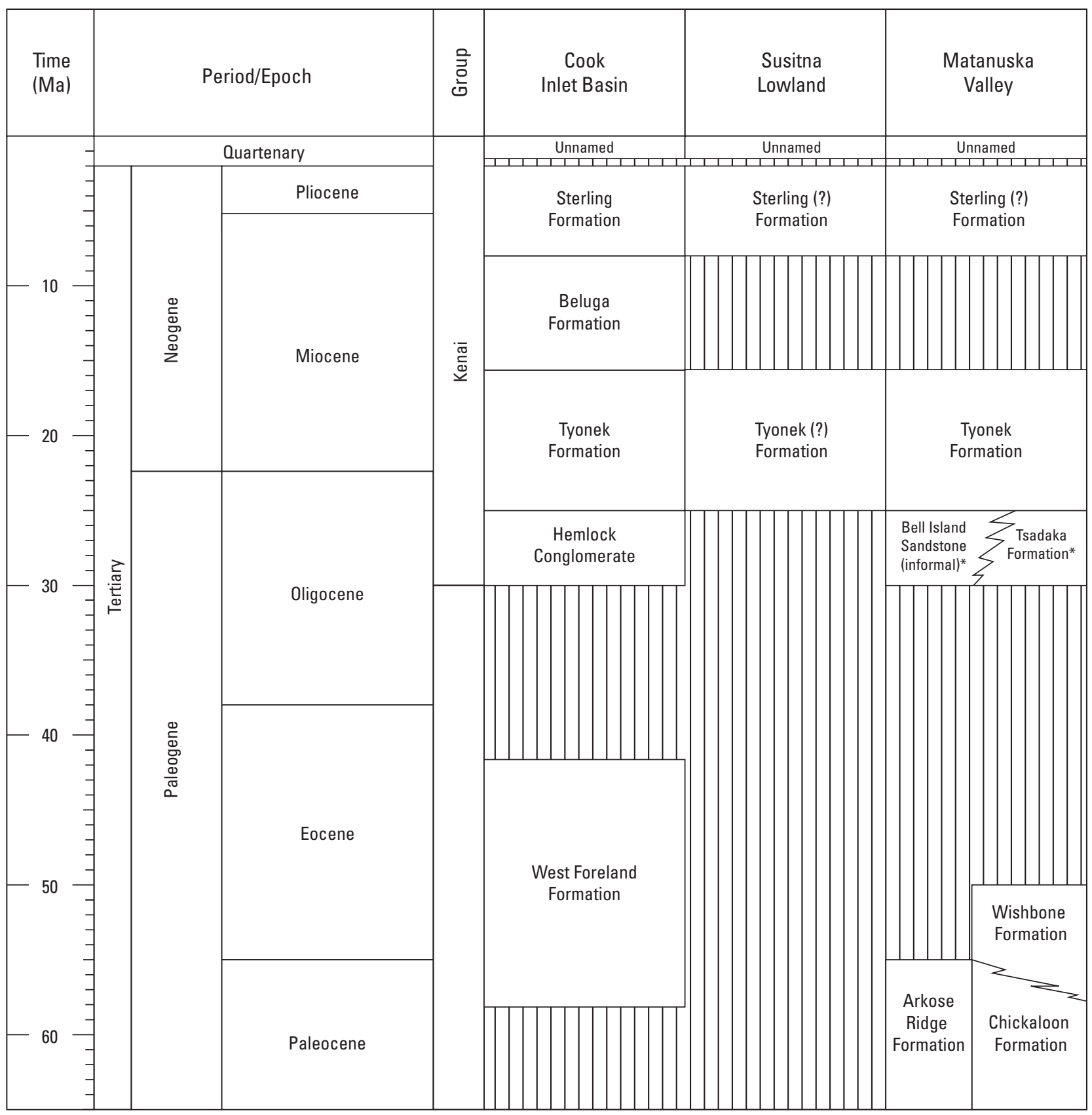

* Not considered part of Kenai Group

Figure 4. Tertiary correlation chart for the Cook Inlet-Susitna region (modified from Wahrhaftig and others, 1994; formations in Susitna lowland from Reed and Nelson, 1980). See Swenson (1997) for interpretation of interfingering relations in Tertiary Strata. ( $\mathrm{Ma}$, million years before present.) 


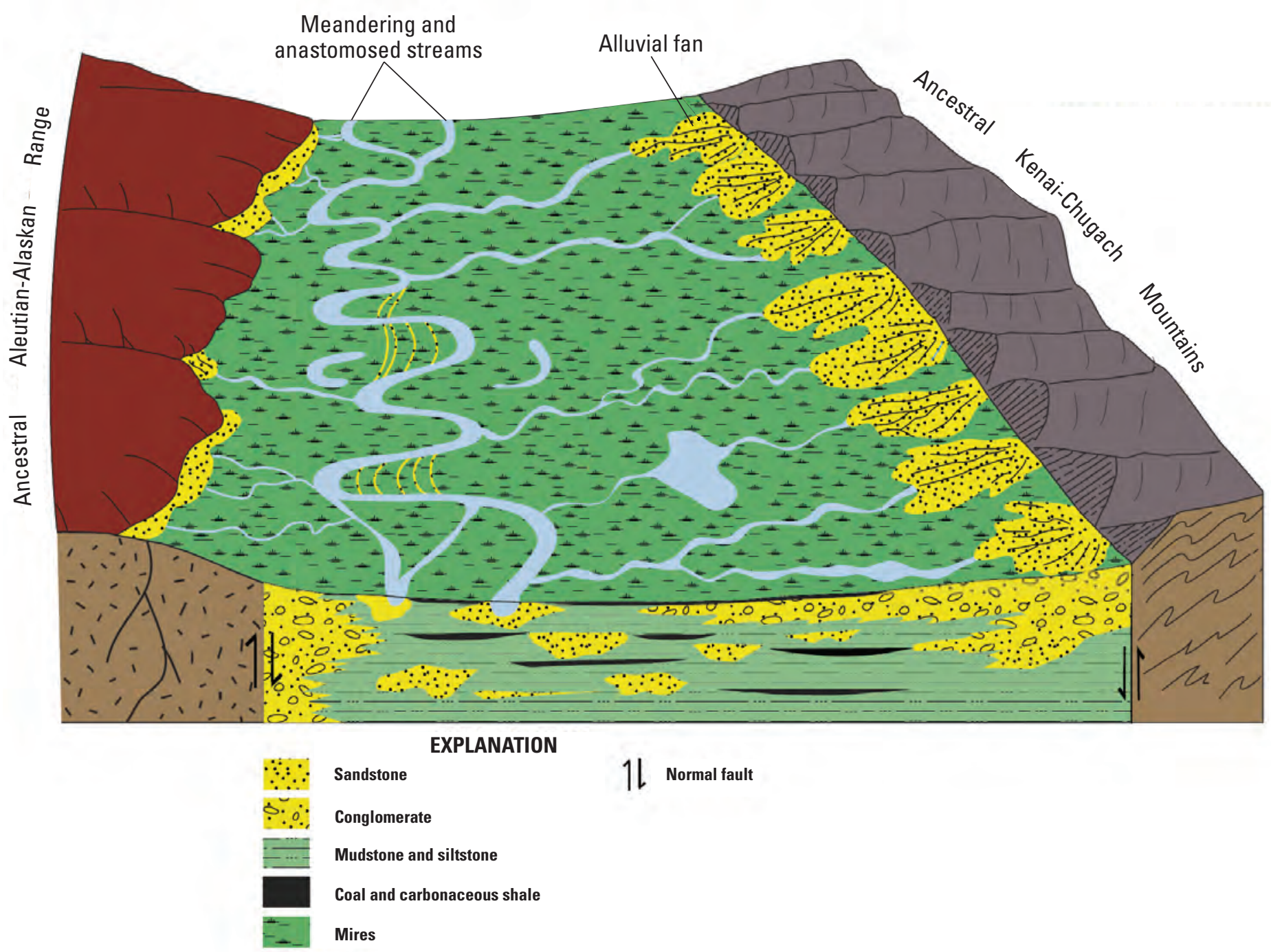

Figure 5. Depositional model of the Kenai Group in the Cook Inlet basin (Flores and others, 2004; modified from Hayes and others, 1976).

The Chickaloon Formation unconformably overlies the Lower and Upper Cretaceous Matanuska Formation, which consists of marine sandstone and shale (Barnes and Payne, 1956; Grantz and Jones, 1960) and is overlain unconformably by the Eocene Wishbone Formation.

The Wishbone Formation consists of 3,000 ft of thick, massive conglomerate and sandstone containing clasts that indicate a provenance in the Talkeetna Mountains to the north. The formation is restricted to the Matanuska Valley and is unconformably overlain by flat-lying Tertiary basalt at the east end of the Matanuska coal field. The Wishbone Formation correlates with the West Foreland Formation in the Cook Inlet basin (Wahrhaftig and others, 1994; Flores and others, 2004).

The West Foreland Formation consists of 2,000 ft of tuffaceous claystone, sandstone, and conglomerate, with a few thin coals. The formation underlies most of the lower Cook Inlet basin southwest of the mouth of the Susitna River and much of the lowland area of the northwestern Kenai Peninsula (Hartman and others, 1971).
The Wishbone and West Foreland Formations are overlain by the Oligocene-Pliocene Kenai Group, though the nature of the contact has been the subject of debate. C.E. Kirschner (1989, written commun.; cited in Wahrhaftig and others, 1994), following the assignment of the West Foreland Formation as the basal unit of the Kenai Group by Calderwood and Fackler (1972), regarded the West Foreland Formation as conformable and probably continuous with the rest of the Kenai Group in the subsurface of the Cook Inlet basin. Kirschner suggested that an unconformity between the West Foreland Formation and parts of the Tyonek Formation observed along the margins of the Cook Inlet basin is spatially restricted to the margins of the basin; however, Magoon and others (1976) regarded the unconformity as regional, because sections of the West Foreland Formation that have been dated are 20 million years older than rocks of the Kenai Group. The USGS has adopted the interpretation of Magoon and others (1976) (Wahrhaftig and others, 1994). 


\section{Upper Tertiary Kenai Group}

The Kenai Group comprises four formations: the Oligocene Hemlock Conglomerate, Oligocene-Middle Miocene Tyonek Formation, Upper Miocene Beluga Formation, and Upper Miocene-Pliocene Sterling Formation (Dall and Harris, 1892; Parkinson, 1962; Calderwood and Fackler, 1972). Most coal shallower than $6,000 \mathrm{ft}$ in the Cook Inlet-Susitna region is in the Kenai Group (Montgomery and Barker, 2003).

The Oligocene Hemlock Conglomerate consists of pebble to boulder conglomerate containing clasts of quartz; chert; metamorphic, volcanic, and plutonic rock fragments; a few thin coal beds; and many siltstone beds. This formation, along with the temporally equivalent Bell Island Sandstone and Tsadaka Formation in the Matanuska Valley, forms a sheet deposit that ranges from 655 to 2,772 ft in thickness (Wolfe and Tanai, 1980; Magoon and Egbert, 1986). Sandstone reservoirs within the formation average 17 percent porosity and 80 millidarcy $(\mathrm{md})$ permeability and represent the main producing horizon for oil in the offshore Cook Inlet (Magoon and Anders, 1990; Magoon, 1994).

The overlying Tyonek, Beluga, and Sterling Formations make up a thick sequence of alluvial sandstone, conglomerate, siltstone, mudstone, carbonaceous shale, and coal, with most of the coal in the Tyonek and Beluga Formations (Wahrhaftig and others, 1994). Sandstone beds are fine to coarse grained, thick, erosive based, crossbedded, and vertically stacked. Individual coal beds range in thickness from a few inches to more than $50 \mathrm{ft}$. Coal rank ranges from lignite in the Sterling Formation to subbituminous in the Tyonek Formation. Subsurface correlation of coal beds from well to well is difficult for distances of more than a mile, suggesting considerable lenticularity of the coal beds and intervening sedimentary rocks. In outcrop, however, individual coal beds have been traced for as far as 6.2 miles (Barnes, 1966; Ramsey, 1981).

\section{Methodology}

Interpretation of geophysical logs from 153 oil and gas exploration wells in the Cook Inlet-Susitna region was used to delineate coal-bed thickness and stratigraphic distribution in the subsurface (fig. 1). This study was limited to wells for which Log ASCII Standard (LAS) files were available. Only vertical and near-vertical wells $(<500$ meters $(\mathrm{m})$ horizontally between surface and bottom-hole locations) with both gamma-ray and bulk density logs were included. Wells that met these criteria were only in the Cook Inlet basin, excluding the Matanuska Valley and Susitna lowland.

Coal beds are readily identified in geophysical logs because of their unique physical properties, including low natural radioactivity and low density. Coal generally exhibits low radioactivity on gamma-ray logs compared to other lithologies in a coal-bearing sequence. Sandstone, however, may have similar gamma-ray values, making identification of coal beds based solely on gamma-ray logs difficult and requiring the use of a supplemental log.

Coal density averages between 0.7 and 1.8 grams per cubic centimeter (g/cc) (Wood and others, 1983), significantly less than associated lithologies. This density contrast is easily recognized on bulk density logs, where coal exhibits low-density spikes (fig. 6). Whereas the bulk density log is capable of identifying thin coal beds, similar density spikes are recorded where the borehole diameter is enlarged as a result of washout. Caliper logs, which measure the diameter of a borehole, can be used to identify areas where low-density measurements may be false (fig. 6).

Net coal-bed thickness between depths of 1,000 and $6,000 \mathrm{ft}$ was quantified as a mapping parameter (fig. 7); explanation for this depth interval is provided below. Coal beds were defined as having bulk density values less than $2 \mathrm{~g} / \mathrm{cc}$. Digital $\operatorname{logs}$ were analyzed by using an automated routine to calculate the thickness of strata with a bulk density less than $2 \mathrm{~g} / \mathrm{cc}$ between depths of $1,000 \mathrm{ft}$ and $6,000 \mathrm{ft}$. These results include borehole washout intervals. Wells that were characterized by intervals of false low density due to borehole washout were removed from net coal thickness calculations in order to prevent overestimates. Nevertheless, logs for most wells likely contain some false low-density values, resulting in overestimates of net coal thickness. Conversely, the lack of a bulk density log curve for any part of the 1,000 - to $6,000-\mathrm{ft}$ depth interval results in an underestimate of net coal thickness. Therefore, net coal thickness derived from log analysis is used as a general parameter to delineate sweet spots of coal-bed gas potential.

In addition to net coal thickness in the 1,000- to $6,000-\mathrm{ft}$ depth interval, individual thick coal deposits were used to further delineate sweet spots of coal-bed gas potential (fig. 8). Individual thick coal deposits are defined as at least $25 \mathrm{ft}$ of coal within a $100-\mathrm{ft}$ interval of section. Wells that were removed from net coal thickness calculations because of borehole washout were manually checked to determine the presence and stratigraphic position of thick coal deposits. 
PENNZOIL CO INC

STARICHKOF STATE UN 1

50831200010000

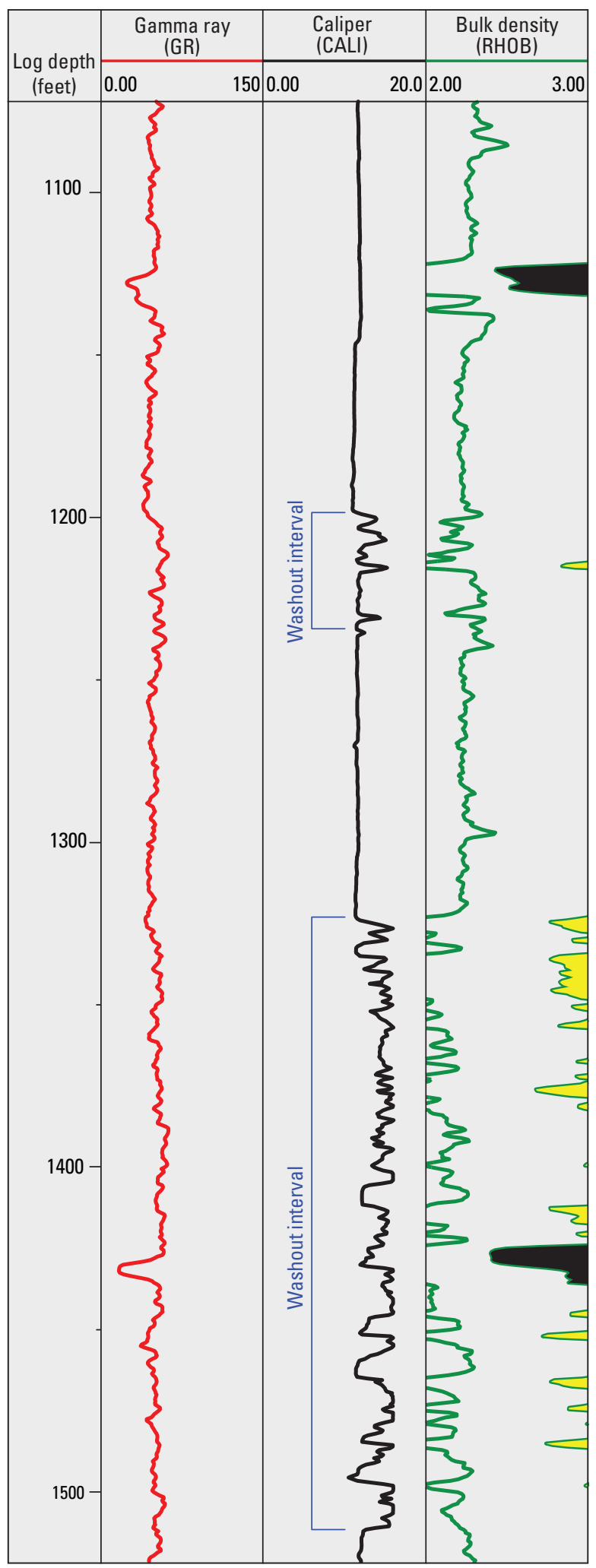

Figure 6. Well log response of coal and borehole washout intervals in the Starichkof State Unit 1 well. Coal beds (black) are identified by both low gamma-ray values ( $G R$, red) and low-density response on the bulk density log curve (RHOB, green). Borehole washout intervals are identified on the caliper log (CALI, black). False low-density measurements associated with borehole washout intervals are highlighted on the bulk density log curve in yellow. 


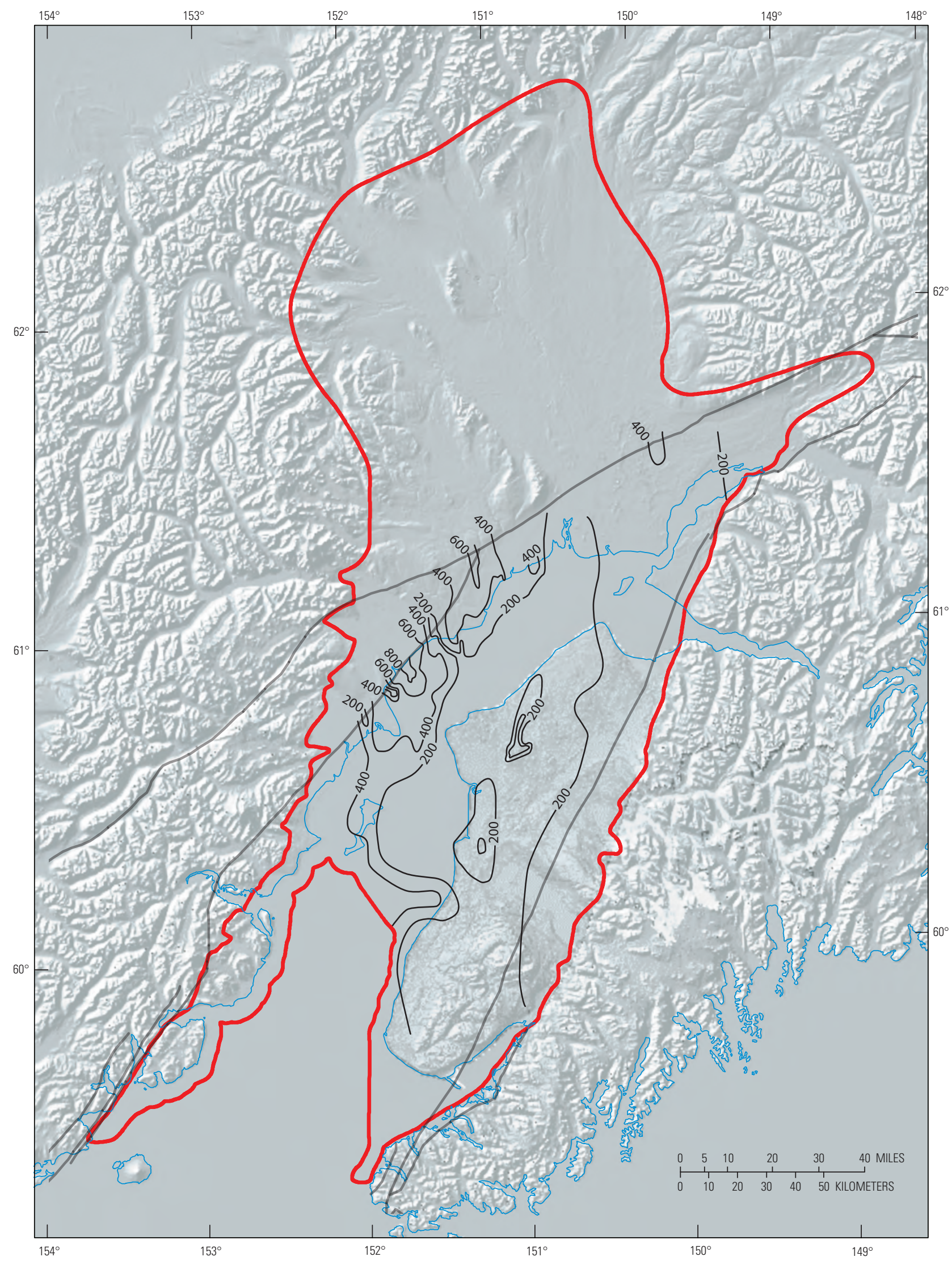

Figure 7. Cumulative thickness of coal (in feet) as inferred from records of wells between 1,000 and 6,000 feet deep in the Cook Inlet basin. 


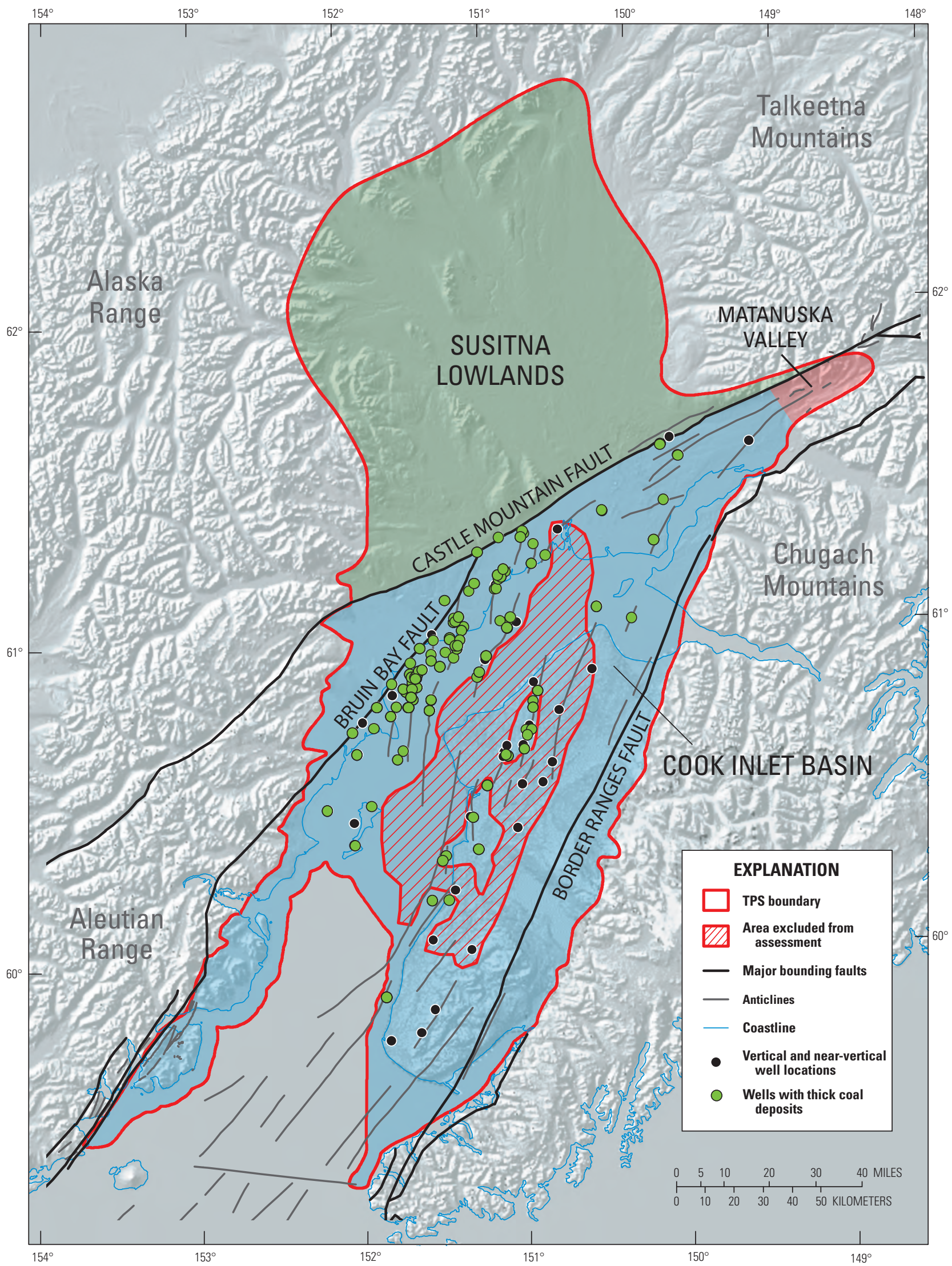

Figure 8. Location of wells with thick coal deposits between depths of 1,000 and 6,000 feet in the Cook Inlet basin. Thick coal deposits (green dots) are defined as at least 25 feet of coal within a 100 -foot interval of section. 


\section{Total Petroleum System}

Assessment of undiscovered, technically recoverable coal-bed gas resources of the Cook Inlet-Susitna region is based on the TPS concept (Schmoker, 2005). A TPS consists of all genetically related petroleum generated by a pod or closely related pods of mature source rocks. The Coal-Bed Gas TPS in the Cook Inlet-Susitna region comprises the Paleocene-Lower Eocene Chickaloon, Oligocene-Middle Miocene Tyonek, Upper Miocene Beluga, and Upper Miocene-Pliocene Sterling Formations, encompassing an area of about 9,600,000 acres. The TPS is divided into homogeneous subunits called assessment units, or AUs. Owing to similarities in lithology and abrupt lateral facies changes in the Chickaloon, Tyonek, Beluga, and Sterling Formations, it is difficult to determine precise and consistent stratigraphic contacts. Therefore, the TPS contains one continuous gas AU in Tertiary coal-bearing strata at depths between 1,000 and $6,000 \mathrm{ft}$. Coal beds generally lose permeability below $6,000 \mathrm{ft}$, and production levels are correspondingly uneconomic (McKee and others, 1986); at depths shallower than $1,000 \mathrm{ft}$, reservoir pressure in coals is assumed to be too low.

An area of approximately 1,100,000 acres within the central part of the Cook Inlet basin was excluded from the assessment because most coal deposits lie deeper than $6,000 \mathrm{ft}$ (figs. 1 and 8). Owing to a paucity of well penetrations and limited seismic coverage, the area excluded from assessment was based mostly on the Mesozoic basement structure contour map (Shellenbaum and others, 2010) (fig. 9). The area excluded from the assessment roughly outlines that area of the basin where depth to basement is greater than $15,000 \mathrm{ft}$. The few wells within the zone excluded from the assessment contained no individual thick coal deposits.

An additional area along the perimeter of the $\mathrm{AU}$ also was excluded from assessment because coal deposits are likely to be shallower than $1,000 \mathrm{ft}$. A paucity of well data made it difficult to constrain this area, resulting in uncertainty in the assessment data input for the total assessment area (see "Assessment Data Input and Results").

\section{Source and Reservoir Rock}

Coal beds within the TPS are the source of gas for both the coal and the conventional accumulations in sandstone reservoirs. Individual coal beds range from a few inches to more than $50 \mathrm{ft}$ in thickness. Coal beds laterally merge, split, and pinch out as influenced by the intervening fluvial-channel sandstones. The net coal-thickness isopach shows that the thickest accumulations of coal between 1,000 and 6,000 ft in depth are along the west shore of the Cook Inlet. Broad areas contain more than $400 \mathrm{ft}$ of net coal, with more than $800 \mathrm{ft}$ locally (fig. 7). Net coal thickness decreases eastward over a 5- to 10-mile distance, and much of the basin contains less than $200 \mathrm{ft}$ of net coal (fig. 7). At least one thick coal deposit between 1,000 and 6,000 ft depth is found in most of the area of the AU (fig. 8).

\section{Maturation}

Thermal maturity of the Cook Inlet-Susitna region was characterized by using published vitrinite reflectance (VR) data from 251 well and outcrop locations (fig. 10). VR in outcrops and the shallow subsurface ranges mostly from 0.18 to 4.18 percent, with values greater than 0.6 percent in the southwestern and northeastern parts of the basin. High reflectance values in the northeastern Matanuska Valley are attributed to tectonic deformation and magmatism along the Aleutian volcanic arc (Flores and others, 2003). The central part of the Cook Inlet basin and Susitna lowland maintains reflectance values of less than 0.6 percent, likely a function of low thermal conductivity related to the rapid rate of subsidence and sedimentation in these areas (Flores and others, 2004). Johnsson and others (1993) determined a similar basinwide variation in thermal maturity from VR at 30 offshore and onshore wells in the Cook Inlet basin.

VR indicates that most coal beds in the Kenai Group are thermally immature $\left(<0.6\right.$ percent reflectance $\left.\left(R_{\mathrm{o}}\right)\right)$, owing to the very low VR gradient with depth (Johnsson and others, 1993). These thermally immature coals range from lignite to subbituminous and are the lowest ranks from which commercial gas is produced in the United States (Flores, 2004).

Claypool and others (1980) identified two types of natural gas occurrences in the Cook Inlet basin separated both stratigraphically and compositionally from each other, suggesting different origins:

- Gas produced from reservoirs sourced from coal beds is both isotopically light $\left(\delta^{13} \mathrm{C}\right.$ range of -63 to -56 per mil) and chemically dry $\left(\mathrm{C}_{1} / \mathrm{C}_{1-5}>0.99\right.$; Claypool and others, 1980). Claypool and others (1980) favored a biogenic origin for gas associated with Tertiary coal beds on the basis of low thermal maturity and isotopically light and chemically dry gas composition.

- VR of coals in the Chickaloon and lower Tyonek Formations in the Matanuska Valley is greater than 0.6 percent $\mathrm{R}_{\mathrm{o}}$, indicating a more mature thermal history. These thermally mature coals range from bituminous to semianthracite in rank. Gas recovered from lower Tyonek Formation coals in the Matanuska Valley is isotopically heavier ( $\delta^{13} \mathrm{C}$ range of -48.9 to -44.0 per mil) than shallow gas of the central and southern Cook Inlet. Given the high-temperature history and heavier gas composition, thermogenic gas is likely in coals in the Matanuska Valley (Smith, 1995, cited in Montgomery and Barker, 2003; Seamount and others, 1997; Barker and others, 2001). 


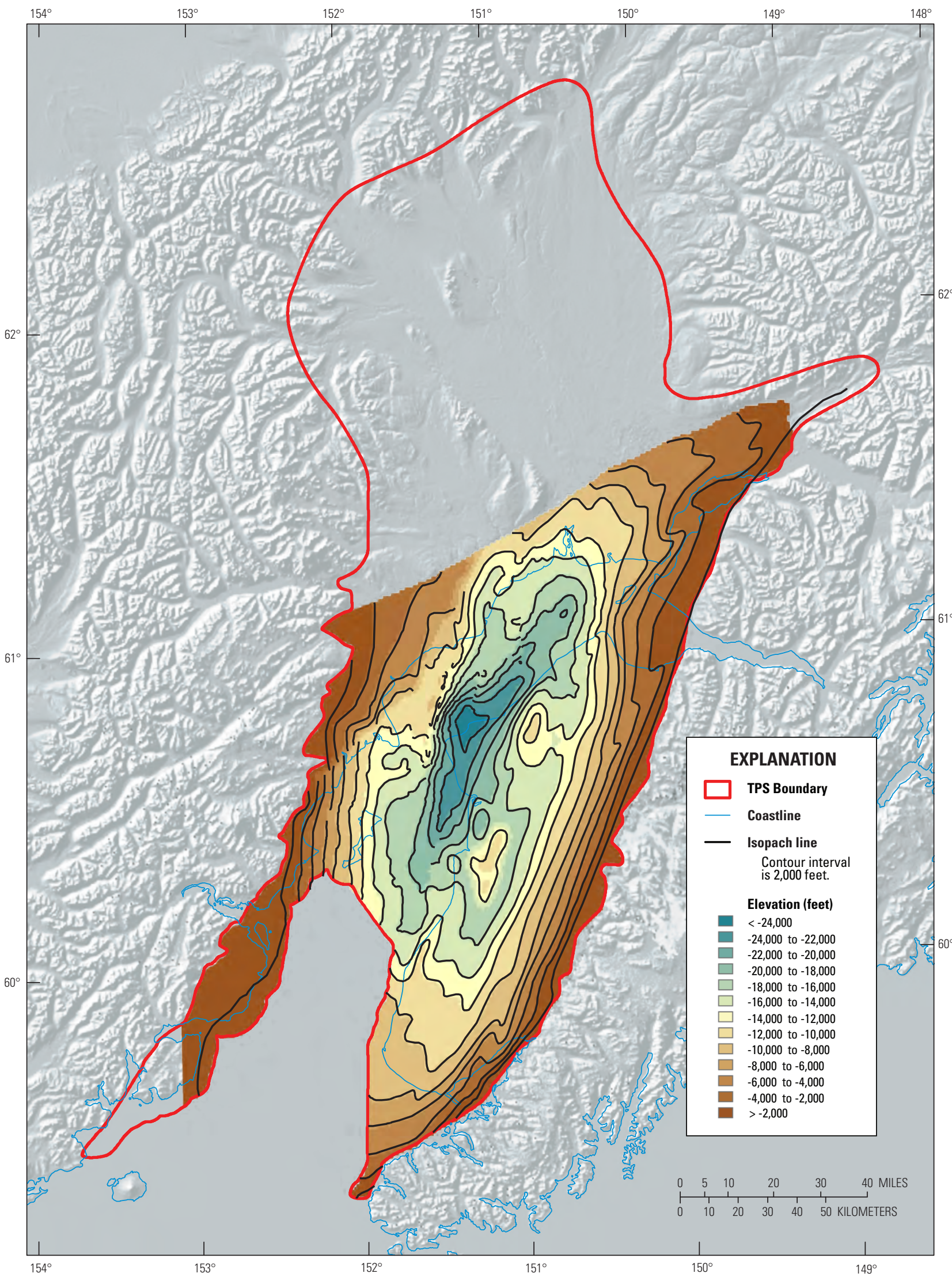

Figure 9. Structure contour map of the top of the Mesozoic basement, Cook Inlet basin (modified from Shellenbaum and others, 2010). 


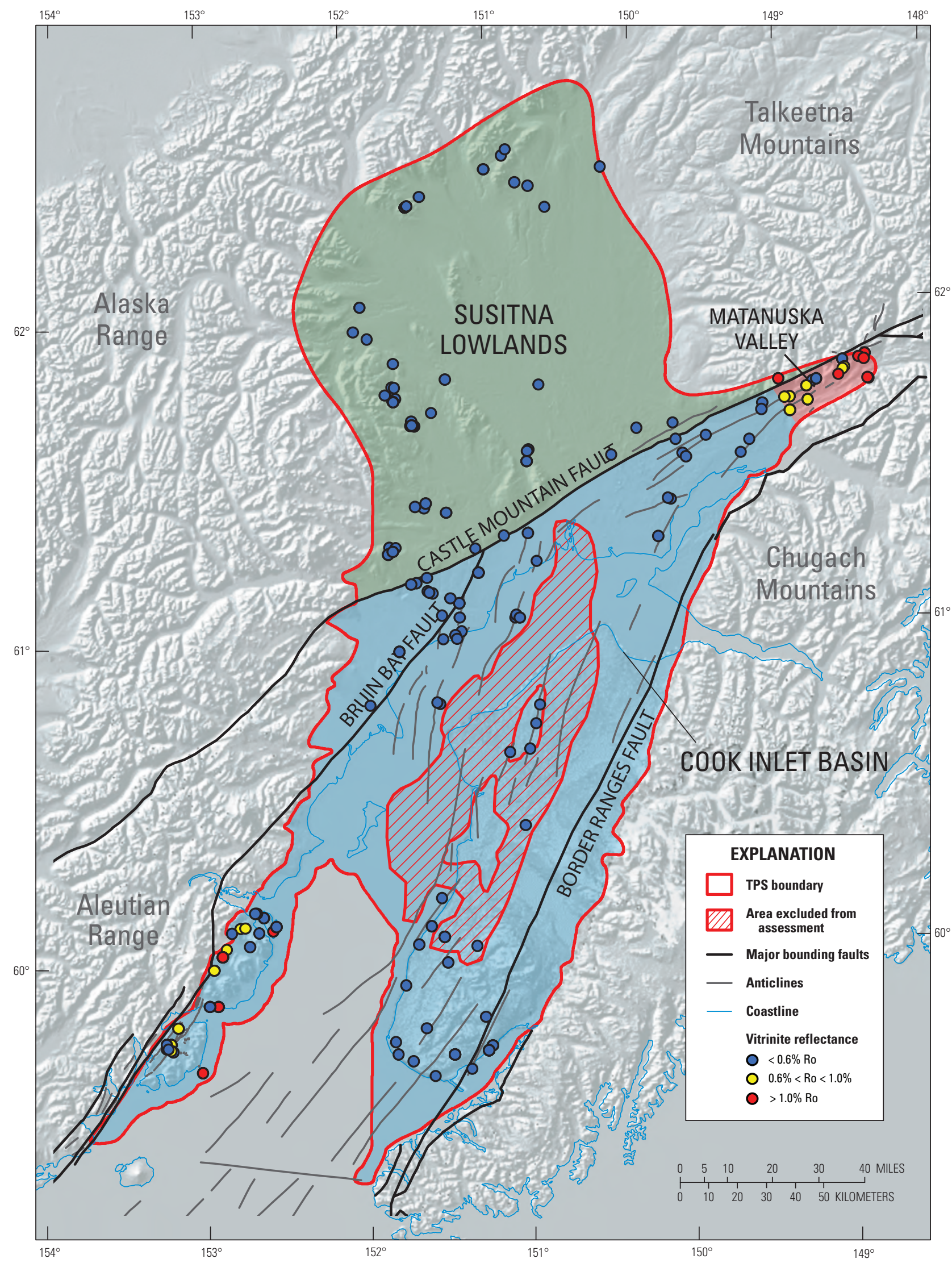

Figure 10. Outcrop and well vitrinite reflectance values within the Coal-Bed Gas Total Petroleum System (TPS) in the Cook Inlet-Susitna region. Vitrinite reflectances from well data are limited to the shallowest data at each well. 


\section{Reservoir Rock}

Coal beds are inferred to serve as both source and reservoir rocks in the Cook Inlet Coal-Bed Gas AU. Coal-bed gas is produced in place and is adsorbed to coal surfaces along fractures, cleats, and pores (Flores, 2004). The amount of gas that coal can store is a function of coal rank, temperature, and pressure (Flores, 2004). Higher rank and pressure generally increase storage capacity, whereas higher temperature decreases storage capacity. Average gas content from canister desorption measurements on subbituminous coal in the central and southern Cook Inlet basin is 60 standard cubic feet per ton (scf/ton), whereas higher rank bituminous coal of the Matanuska Valley has an average gas content of $230 \mathrm{scf} /$ ton (Barker and others, 2001).

\section{Assessment Data Input and Results}

The basic input data used for the assessment of Tertiary coal-bed gas in the Cook Inlet-Susitna region are listed in table 1. The AU is considered hypothetical because no production has been established from Tertiary coal-bed reservoirs, so the use of coal-bed gas analogs from the 48 contiguous States was necessary for this assessment. Coal beds of the Upper Fort Union Formation in the Powder River Basin of Wyoming and Montana were selected as a baseline production analog for Tertiary coal beds in the Cook Inlet-Susitna region. Upper Fort Union coal beds have the same rank (lignite to subbituminous) and similar coal-quality characteristics to coal beds of the Tertiary Kenai Group (Flores, 2004). Although coals of higher rank and greater gas storage capacity have been documented in the northeastern Matanuska Valley, they were not considered separately because (1) they are thought to be spatially limited to an area along the northeastern part of the Castle Mountain fault, (2) the subsurface extent of the higher rank coals is poorly constrained, and (3) their reservoir properties are thought to be influenced by strain related to the Castle Mountain fault and contact metamorphism by igneous dikes and sills (Barnes, 1962; Merritt, 1985; Stricker, 1991; Wahrhaftig and others, 1994).

The Tertiary Coal-Bed Gas AU is considered to have a minimum estimated ultimate recovery (EUR) per cell of 0.02 billion cubic feet of gas (BCFG) in this assessment. The assessment area contains an estimated minimum of $8,000,000$ acres, mode of $8,500,000$ acres, and maximum of 9,000,000 acres because of uncertainties in geologic map boundaries (table 1). The drainage area of untested cells having potential for additions to reserves is estimated at a minimum of 40 acres, a mode of 80 acres, and a maximum of 140 acres (table 1), values similar to those estimated for the Upper Fort Union Formation AU (Flores, 2004). All of the AU area is untested (table 1). The fraction of total AU area that has potential for additions to reserves in the next 30 years is estimated at a minimum of 0.5 percent, a mode of 6 percent, and a maximum of 63 percent (table 1). The mode percentage is based on the area of thick coal accumulation between 1,000 and 6,000 ft in depth near the western shore of the Cook Inlet relative to the total AU area. The minimum and maximum percentages reflect considerable uncertainty that stems from the absence of subsurface penetrations that meet the assessment criteria in more than 30 percent of the assessment unit (Susitna lowland and Matanuska Valley). The total recovery per cell for untested cells having potential for addition to reserves in the next 30 years was estimated at a minimum of $0.02 \mathrm{BCFG}$, a median of $0.16 \mathrm{BCFG}$, and a maximum of 1.5 BCFG (table 1). Using these inputs, the USGS estimates the total undiscovered coal-bed gas resources in the Cook Inlet-Susitna region as follows: $1,581 \mathrm{BCFG}$ at $\mathrm{F}_{95}$, $3,989 \mathrm{BCFG}$ at $\mathrm{F}_{50}$, and $10,069 \mathrm{BCFG}$ at $\mathrm{F}_{5}$; the mean estimate is 4,674 BCFG (table 2). 
Table 1. Assessment data input for the Cook Inlet Coal-Bed Gas Assessment Unit.

\section{NUMBER OF UNTESTED CELLS WITH POTENTIAL FOR ADDITIONS TO RESERVES}

1. Total assessment-unit area (acres): (uncertainty of a fixed value)

calculated mean $\quad 8,500,000 \quad$ minimum $\quad$ 8,000,000 mode $\quad 8,500,000 \quad$ maximum $\underline{9,000,000}$

2. Area per cell of untested cells having potential for additions to reserves (acres): (values are inherently variable)

\begin{tabular}{|c|c|c|c|c|c|c|c|}
\hline calculated mean & 87 & minimum & 40 & mode & 80 & maximum & 140 \\
\hline mean: & minimum & 40 & maximum & 120 & & & \\
\hline
\end{tabular}

3. Percentage of total assessment-unit area that is untested (percent): (uncertainty of a fixed value)

calculated mean $\quad 100 \quad$ minimum $\quad 100 \quad$ mode $\quad 100 \quad$ maximum $100 \quad$

4. Percentage of untested assessment-unit area that has potential for additions to reserves (percent):

(a necessary criterion is that total recovery per cell $\geq$ minimum; uncertainty of a fixed value)
calculated mean
23
minimum
0.5
mode

6

maximum

63

\section{TOTAL RECOVERY PER CELL}

Total recovery per cell for untested cells having potential for additions to reserves:

(values, in billion cubic feet of gas, are inherently variable)

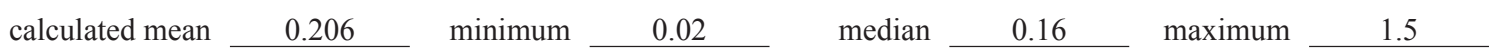

Table 2. Summary of results for risked, undiscovered, technically recoverable contiguous gas resources for the Cook Inlet Coal-Bed Gas Assessment Unit.

[BCFG, billion cubic feet of gas. Undiscovered gas resources are the sum of nonassociated and associated gas. $\mathrm{F}_{95}$ represents a 95-percent chance of at least the amount tabulated; other fractiles are defined similarly]

\begin{tabular}{ccccc}
\hline \multirow{2}{*}{ Assessment unit name } & \multicolumn{4}{c}{ Total undiscovered gas resources (BCFG) } \\
\cline { 2 - 5 } & $\mathbf{F}_{95}$ & $\mathbf{F}_{50}$ & $\mathbf{F}_{5}$ & Mean \\
\hline Cook Inlet Coal-Bed Gas & 1,581 & 3,989 & 10,069 & 4,674 \\
\hline
\end{tabular}




\section{Summary}

The Cook Inlet Coal-Bed Gas Total Petroleum System (TPS) of south-central Alaska comprises coal-bearing Tertiary strata of the Cook Inlet basin, Matanuska Valley, and Susitna lowland. The TPS contains one hypothetical assessment unit (AU) that was evaluated for coal-bed gas resources between 1,000 and 6,000 ft in depth over an area of about $8,500,000$ acres. Coal beds, which range in thickness from a few inches to more than $50 \mathrm{ft}$, were deposited in mires associated with a large trunk-tributary fluvial system. Gas associated with the lignite to subbituminous coal in the AU is likely biogenic in origin. Potential for addition to reserves in the next 30 years is greatest along the western part of the Cook Inlet basin, where cumulative coal thickness exceeds $800 \mathrm{ft}$. Using coal beds of the Upper Fort Union Formation in the Powder River Basin of Wyoming and Montana as a baseline production analog, the USGS estimates the total undiscovered coal-bed gas resources in the Cook Inlet Coal-Bed Gas AU as follows: $1,581 \mathrm{BCFG}$ at $\mathrm{F}_{95}, 3,989 \mathrm{BCFG}$ at $\mathrm{F}_{50}$, and $10,069 \mathrm{BCFG}$ at $\mathrm{F}_{5}$; the mean estimate is $4,674 \mathrm{BCFG}$ (table 2).

\section{References Cited}

Affolter, R.H., and Stricker, G.D., 1987, Offshore Alaska coal, in Scholl, D.W., Grantz, Arthur, and Vedder, J.G., eds., Geology and resource potential of the continental margin of western North America and adjacent ocean basins-Beaufort Sea to Baja California: Houston, Tex., Circum-Pacific Council for Energy and Mineral Resources, Earth Science Series, v. 6, p. 639-647.

Alaska Department of Natural Resources, Division of Oil and Gas, 2009, Historical and projected oil and gas consumption: p. 26.

Barker, C.E., Dallegge, T.A., and Seamount, D.C., 2001, Ongoing coalbed desorption studies, Cook Inlet Basin, Alaska [abs.], in Dallegge, T.A., comp., Guide to the petroleum, geology, and shallow gas potential of the Kenai Peninsula, Alaska: 2001 Petroleum Technology Transfer Council, Alaska Department of Natural Resources and U.S. Geological Survey Alaska Coalbed and Shallow Gas Resources Workshop, Field Trip Guidebook, p. 40-55.

Barnes, F.F., 1962, Variation in rank of Tertiary coals in the Cook Inlet basin, Alaska: U.S. Geological Survey Professional Paper 450-C, p. C14-C16.

Barnes, F.F., 1966, Geology and coal resources of the BelugaYentna region, Alaska: U.S. Geological Survey Bulletin 1202-C, p. C1-C34, pls. 1-7.

Barnes, F.F., 1967, Coal resources of Alaska: U.S. Geological Survey Bulletin 1242-B, p. B1-B36, pl. 1.
Barnes, F.F., and Cobb, E.H., 1959, Geology and coal resources of the Homer district, Kenai coal field, Alaska: U.S. Geological Survey Bulletin 1058-F, p. 217-258, pls. 17-28.

Barnes, F.F., and Payne, T.G., 1956, The Wishbone Hill district, Matanuska coal field, Alaska: U.S. Geological Survey Bulletin 1016, 88 p., 20 pl.

Byrne, Tim, 1979, Late Paleocene demise of the Kula-Pacific spreading center: Geology, v. 7, p. 341-344.

Calderwood, K.W., and Fackler, W.C., 1972, Proposed stratigraphic nomenclature for Kenai Group, Cook Inlet Basin, Alaska: American Association of Petroleum Geologists Bulletin, v. 56, p. 739-754.

Claypool, G.E., Threlkeld, C.N., and Magoon, L.B., 1980, Biogenic and thermogenic origins of natural gas in Cook Inlet basin, Alaska: American Association of Petroleum Geologists Bulletin, v. 64, no. 8, p. 1131-1139.

Dall, W.H., and Harris, G.D., 1892, Correlation papersNeocene: U.S. Geological Survey Bulletin 84, 349 p.

Davis, T.N., 1981, Alaska's Coal, article \#492, June 26, 1981: Geophysical Institute, University of Alaska Fairbanks.

Flores, R.M., 2004, Coalbed methane in the Powder River Basin, Wyoming and Montana-An assessment of the Tertiary-Upper Cretaceous Coalbed Methane Total Petroleum System, in Total Petroleum System and assessment of coalbed gas in the Powder River Basin Province, Wyoming and Montana: U.S. Geological Survey Digital Data Series DDS-69-C, chap. 2, 56 p.

Flores, R.M., and Stricker, G.D., 1993, Early Cenozoic depositional systems, Wishbone Hill District, Matanuska coal field, Alaska, in Dusel-Bacon, Cynthia, and Till, A.B., eds, Geologic studies in Alaska by the Geological Survey, 1992: U.S. Geological Survey Bulletin 2068, p. 101-117.

Flores, R.M., Stricker, G.D., and Kinney, S.A., 2003, Alaska coal resources and coalbed methane potential: U.S. Geological Survey Bulletin 2198, 4 p.

Flores, R.M., Stricker, G.D., and Kinney, S.A., 2004, Alaska coal geology, resources, and coalbed methane potential: U.S. Geological Survey Digital Data Series DDS-77, version 1.0 (2004) 140 p. [CD-ROM]. (Also available at http://pubs.usgs.gov/dds/2004/77/.)

Grantz, Arthur, and Jones, D.L., 1960, Stratigraphy and age of the Matanuska Formation: U.S. Geological Survey Professional Paper 400-B, p. B347-B350. 
Haeussler, P.J., Bruhn, R.L., and Pratt, T.L., 2000, Potential seismic hazards and tectonics of the upper Cook Inlet basin, Alaska, based on analysis of Pliocene and younger deformation: Geological Society of America Bulletin, v. 112, no. 9, p. 1414-1429.

Hartman, D.C., Pessel, G.H., and McGee, D.L., 1971, Preliminary report on stratigraphy of the Kenai group, upper Cook Inlet, Alaska: Alaska Division of Geological \& Geophysical Surveys Special Report 5, 4 p., 10 pl.

Hopkins, D.M., 1951, Lignite deposits near Broad Pass Station, Alaska: U.S. Geological Survey Bulletin 963-E, p. 187-191, pl. 26.

Hayes, J.B., Harms, J.C., and Wilson, T., 1976, Contrasts between braided and meandering stream deposits, Beluga and Sterling Formations (Tertiary), Cook Inlet, Alaska, in Miller, T.P., ed., Recent and ancient sedimentary environments in Alaska-Proceedings, Alaska Geological Society Symposium, April 2-4, 1975, Anchorage: Alaska Geological Society, p. J1-J27.

Johnsson, M.J., Howell, D.G., and Bird, K.J., 1993, Thermal maturity patterns in Alaska-Implications for tectonic evolution and hydrocarbon potential: American Association of Petroleum Geologists Bulletin, v. 77, p. 1874-1903.

Kelly, T.E., 1963, Geology and hydrocarbons in Cook Inlet basin, Alaska, in Childs, O.E., and Beebe, B.W., eds., Backbone of the Americas-A symposium: American Association of Petroleum Geologists Memoir 2, p. 278-296.

Magoon, L.B., 1994, Tuxedni-Hemlock(!) petroleum system in Cook Inlet, Alaska, U.S.A., in Magoon, L.B., and Dow, W.G., eds., The petroleum system-From source to trap: American Association of Petroleum Geologists Memoir 60, p. 359-370.

Magoon, L.B., Adkison, W.L., and Egbert, R.M., 1976, Map showing geology, wildcat wells, Tertiary plant fossil localities, K-Ar age dates, and petroleum operations, Cook Inlet area, Alaska: U.S. Geological Survey Miscellaneous Investigations Series Map I-1019, 3 sheets, scale 1:250,000.

Magoon, L.B., and Anders, D.E., 1990, Oil-source rock correlation using carbon isotope data and biological marker compounds, Cook Inlet, Alaska peninsula, Alaska: American Association of Petroleum Geologists Bulletin, v. 74, p. 711.

Magoon, L.B., and Egbert, R.M., 1986, Framework geology and sandstone composition, in Magoon, L.G., ed., Geologic studies of the Lower Cook Inlet COST No. 1 Well, Alaska outer continental shelf: U.S. Geological Survey Bulletin 1596, p. 65-90.
McKee, C.R., Bumb, A.C., Way, S.C., Koenig, R.A., Reverand, J.M., and Brandenburg, C.F., 1986, Using permeability-vs-depth correlations to assess the potential for producing gas from coal seams: Methane From Coal-Seams Technology, v. 4, p. 15-26.

Merritt, R.D., 1985, Review of coking phenomena in relation to an occurrence of prismatically fractured natural coke from the Castle Mountain mine, Matanuska coal field, Alaska: International Journal of Coal Geology, v. 4, p. 281-298.

Merritt, R.D., and Belowich, M.A., 1984, Coal geology and resources of the Matanuska Valley, Alaska: Alaska Division of Geological \& Geophysical Surveys Report of Investigations 84-24, 64 p., 3 pl.

Merritt, R.D., and Hawley, C.C., comps., 1986, Map of Alaska's coal resources: Fairbanks, Alaska Division of Geological \& Geophysical Surveys, scale 1:2,500,000.

Miller, R.D., and Dobrovolny, Ernest, 1959, Surficial geology of Anchorage and vicinity, Alaska: U.S. Geological Survey Bulletin 1093, $128 \mathrm{p}$.

Montgomery, S.L., and Barker, C.E., 2003, Coalbed methane, Cook Inlet, south-central Alaska-A potential giant gas resource: American Association of Petroleum Geologists Bulletin, v. 87, no. 1, p. 1-13.

Nokelberg, W.J., Plafker, George, and Wilson, F.H., 1994, Geology of south-central Alaska, in Plafker, G., and Berg, H.C., eds., The geology of North America-The geology of Alaska: Boulder, Colo., Geological Society of America, v. G-1, p. 311-366.

Parkinson, L.J., 1962, One field, one giant-The story of the Swanson River: Oil and Gas Journal, v. 60, no. 13, p. $180-183$.

Plafker, George, Bruns, T.R., Winkler, G.R., and Tysdal, R.G., 1982, Cross section of the eastern Aleutian arc, from Mount Spurr to the Aleutian trench near Middleton Island, Alaska: Geological Society of America, Map and Chart Series, MC-28P, scale 1:1,000,000.

Plafker, George, Moore, J.C., and Winkler, G.R., 1994, Geology of the southern Alaska margin, in Plafker, George, and Berg, H.C., eds., The geology of North America-The geology of Alaska: Boulder, Colo., Geological Society of America, v. G-1, p. 389-449.

Pavlis, T.L., 1982, Origin and age of the Border Ranges fault of southern Alaska and its bearing on the Late Mesozoic tectonic evolution of Alaska: Tectonics, v. 1, no. 4, p. $343-368$. 
Ramsey, J.P., 1981, Geology-coal resources and mining plan for the Chuitna Coal '80 (Conference proceedings, University of Alaska, Fairbanks, October 21-23, 1980): University of Alaska, Mineral Industries Research Laboratory Report 50, p. 111-121.

Reed, B.L., and Nelson, S.W., 1980, Geologic map of the Talkeetna quadrangle, Alaska: U.S. Geological Survey Miscellaneous Investigations Series Map I-1174, scale $1: 250,000,15 \mathrm{p}$.

Renshaw, D.E., 1983, Matanuska-Susitna Borough—Summary of mineral resources: Palmer, Alaska, Mapmakers, report prepared under grant from State of Alaska Division of Geological \& Geophysical Surveys, p. 40-41.

Schmoker, J.W., 2005, U.S. Geological Survey assessment concepts for continuous petroleum accumulations, in Petroleum systems and geologic assessment of oil and gas in the southwestern Wyoming Province, Wyoming, Colorado, and Utah: U.S. Geological Survey Digital Data Series DDS-69-D, chap. 13, 7 p.

Seamount D.T., Cross, R., and Buck, G., 1997, Geologic and engineering report to accompany application for approval for unitization of the Pioneer Unit, State of Alaska, December 10, 1997: Alaska Department of Natural Resources, Division of Oil and Gas, 47 p.

Shellenbaum, D.P., Gregersen, L.J., and Delaney, P.R., 2010, Top Mesozoic unconformity depth map of the Cook Inlet Basin, Alaska: Fairbanks, Alaska Division of Geological \& Geophysical Surveys, Report of Investigations 2010-2, 1 sheet, scale 1:500,000.

Smith, T.N., 1995, Coalbed methane potential for Alaska and drilling results for the upper Cook Inlet Basin, in Proceedings, Intergas, May 15-19, 1995, Tuscaloosa, Ala., University of Alabama: p. 1-21.
Stanley, R.G., Charpentier, R.R., Cook, T.A., Houseknecht, D.W., Klett, T.R., Lewis, K.A., Lillis, P.G., Nelson, P.H., Phillips, J.D., Pollastro, R.M., Potter, C.J., Rouse, W.A., Saltus, R.W., Schenk, C.J., Shah, A.K., and Valin, Z.C., 2011, Assessment of undiscovered oil and gas resources of the Cook Inlet region, south-central Alaska, 2011: U.S. Geological Survey Fact Sheet 2011-3068, 2 p.

Stricker, G.D., 1991, Economic Alaskan coal deposits, in Gluskoter, H.J., Rice, D.D., and Taylor, R.B., eds., Economic geology, U.S.: Geological Society of America, The Geology of North America, v. P-2, p. 591-602.

Swenson, R.F., 1997, Introduction to Tertiary tectonics and sedimentation in the Cook Inlet Basin, in Karl-Vaughn, N.R., and Ryherd, T.J., eds., Guide to the geology of the Kenai Peninsula, Alaska: Geological Society of Alaska, p. $18-27$.

Triplehorn, D.M., Turner, D.L., and Naeser, C.W., 1984, Radiometric age of the Chickaloon Formation of south-central Alaska-Location of the Paleocene-Eocene boundary: Geological Society of America Bulletin, v. 95, p. 740-742.

Wahrhaftig, C., Bartsch-Winkler, S., and Stricker, G.D., 1994, Coal in Alaska, in Plafker, George, and Berg, H.C., eds., The geology of North America-The geology of Alaska: Boulder, Colo., Geological Society of America, v. G-1, p. 937-978.

Wolfe, J.A., and Tanai, Toshimasa, 1980, The Miocene Seldovia Point flora from the Kenai Group, Alaska: U.S. Geological Survey Professional Paper 1105, 52 p., $25 \mathrm{pl}$.

Wood, G.H., Jr., Kehn, T.M., Carter, M.D., and Culbertson, W.C., 1983, Coal resource classification system of the U.S. Geological Survey: U.S. Geological Survey Circular 891, $65 \mathrm{p}$. 




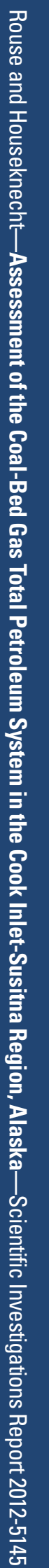

